\title{
'Auto-collateral' from the second diagonal branch to the left anterior descending artery
}

\author{
Manish Shaw, Niraj Nirmal Pandey, Mumun Sinha, Sanjeev Kumar
}

Cardiovascular Radiology and Endovascular Interventions, All India Institute of Medical Sciences, New Delhi, India

\section{Correspondence to} Dr Sanjeev Kumar, sanjeevradio@gmail.com

Accepted 1 April 2019

\section{DESCRIPTION}

A 40-year-old male patient presented with recentonset atypical retrosternal chest pain, having low to intermediate probability of coronary artery disease. CT angiography (CTA) was performed to evaluate the coronaries, which revealed chronic total occlusion (CTO) of the left anterior descending (LAD) artery distal to the origin of the second diagonal branch (D2) with reformation of a distal LAD artery. The D2 was tortuous and coursing along the left ventricular (LV) epicardial surface and seen to supply the distal LAD artery myocardial territory via an epicardial collateral at the LV apex. The LAD artery segment distal to the occlusion was good sized and showed no significant disease (figure 1). A mixed plaque in the proximal LAD artery causing moderate stenosis was also noted along with diffuse significant atherosclerotic disease involving the right coronary artery (RCA) and left circumflex (LCx) artery.

The most commonly observed collaterals in cases of CTO of LAD artery are from the septal branch of the posterior descending artery, right atrial and right ventricular branches of RCA and obtuse marginal branches of LCx artery. ${ }^{1}$ However, in our case, the sole collateral reforming the LAD artery was from the hypertrophied D2 branch of the LAD itself arising proximal to the occluded segment, understandably termed an 'auto-collateral'. The other more commonly observed collaterals were not present owing to significant disease in the RCA and LCx artery and hence, the epicardial collateral from D2 might have increased in size according to the perfusion gradients. Identification of this large collateral on CTA will have a significant impact on the planning of any retrograde percutaneous
A) Check for updates

(C) BMJ Publishing Group Limited 2019. No commercial re-use. See rights and permissions. Published by BMJ.

To cite: Shaw M, Pandey NN, Sinha M, et al. BMJ Case Rep 2019;12:e229586. doi:10.1136/bcr-2019229586

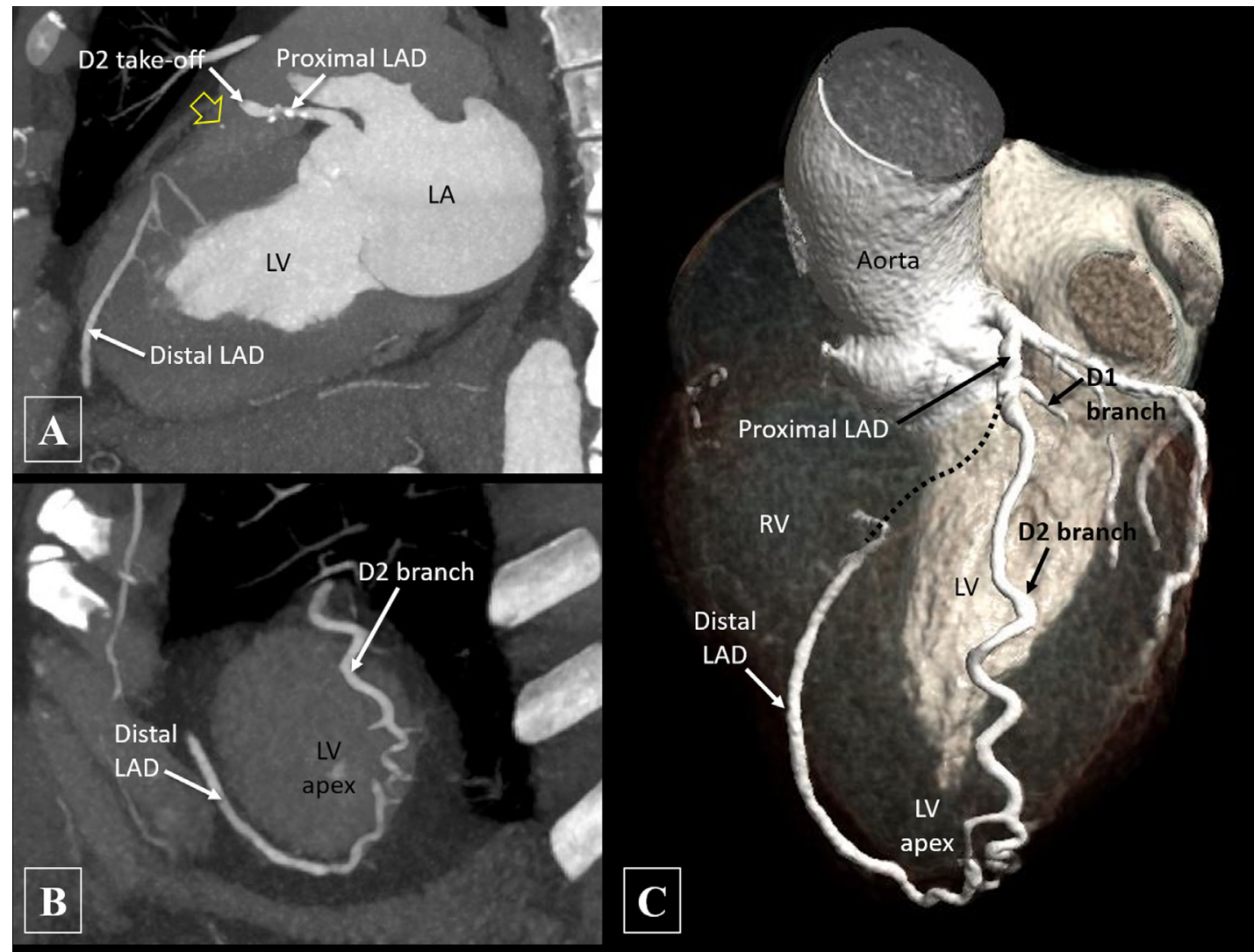

Figure 1 Oblique sagittal (A) and oblique coronal (B) maximum intensity projection images of CT angiography and volume rendered image (C) shows calcific plaques in proximal left anterior descending (LAD) artery with chronic total occlusion of the LAD distal to origin of the second diagonal branch (D2). A calcific speck (yellow arrow) is noted along the expected course of the occluded LAD segment (indicated by dashed line). The second diagonal branch is tortuous and seen supplying the distal LAD at the left ventricular apex via an epicardial collateral. D1, first diagonal branch; LA, left atrium; LV, left ventricle; RV, right ventricle. 
intervention when indicated. Having a beforehand knowledge of the pathological anatomy would allow an informed decision regarding approach to revascularisation as well as optimum hardware selection, thus increasing the procedural efficacy. ${ }^{2}$

\section{Learning points}

Commonly observed collaterals in cases of chronic total occlusion of left anterior descending artery are from the septal branch of the posterior descending artery, right atrial and right ventricular branches of right coronary artery and obtuse marginal branches of left circumflex artery.

- In some cases, collaterals from the left anterior descending artery branches arising proximal to occlusion may reform it distal to the occlusion and are understandably termed 'auto-collaterals'.

- Identification of such large collaterals will have significant impact on the planning of any retrograde percutaneous intervention whenever indicated.
However, considering the limitations of CTA in optimally visualising small collaterals owing to suboptimal opacification of very small vessels, it should also be kept in mind that a subsequent catheter angiography may reveal other collateral pathways which may be safer or more appropriate for use during percutaneous intervention.

Contributors MSh, NNP, MSi and SK have participated sufficiently in the conception of the idea, development of the intellectual content, design, writing and final approval of the manuscript.

Funding The authors have not declared a specific grant for this research from any funding agency in the public, commercial or not-for-profit sectors.

Competing interests None declared.

Patient consent for publication Obtained.

Provenance and peer review Not commissioned; externally peer reviewed.

\section{REFERENCES}

1 Levin DC. Pathways and functional significance of the coronary collateral circulation. Circulation 1974;50:831-7.

2 McEntegart MB, Badar AA, Ahmad FA, et al. The collateral circulation of coronary chronic total occlusions. Eurolntervention 2016;11:e1596-603.

Copyright 2019 BMJ Publishing Group. All rights reserved. For permission to reuse any of this content visit https://www.bmj.com/company/products-services/rights-and-licensing/permissions/

BMJ Case Report Fellows may re-use this article for personal use and teaching without any further permission.

Become a Fellow of BMJ Case Reports today and you can:

- Submit as many cases as you like

- Enjoy fast sympathetic peer review and rapid publication of accepted articles

- Access all the published articles

- Re-use any of the published material for personal use and teaching without further permission

For information on Institutional Fellowships contact consortiasales@bmjgroup.com

Visit casereports.bmj.com for more articles like this and to become a Fellow 